\title{
Agenesis of internal carotid artery associated with isolated growth hormone deficiency: a case report and literature review
}

\author{
Stefano Stagi ${ }^{1 *}$, Giovanna Traficante ${ }^{2}$, Elisabetta Lapi ${ }^{2}$, Marilena Pantaleo ${ }^{2}$, Sabrina Becciani ${ }^{1}$, Marzia Mortilla ${ }^{3}$,
} Salvatore Seminara ${ }^{1}$ and Maurizio de Martino ${ }^{1}$

\begin{abstract}
Background: Agenesis of the internal carotid artery (ICA) is a rare congenital abnormality, sporadically reported to be associated with a combined congenital hypopituitarism. Nevertheless, only a few cases have been extensively described, and none of these have been characterized by an isolated growth hormone (GH) deficiency.

Case presentation: Here, we describe a 17-year old boy referred to our hospital for fatigue, decreased muscle strength and severe headache reported after the cessation of rhGH treatment for a $\mathrm{GH}$ deficiency diagnosed at the age of 2 years and 3 months. Magnetic resonance imaging (MRI) showed an adenohypophyseal hypoplasia with a lack of posterior pituitary hyperintensity, whereas MRI angiography indicated the absence of a normal flow void in the left ICA. Endocrinological tests confirmed the GH deficiency (GH peak after growth-hormone-releasing hormone $(\mathrm{GHRH})+$ arginine: $2.42 \mathrm{ng} / \mathrm{mL})$ with a very low $\mathrm{GGF}-\mathrm{I}$ value $(31 \mathrm{ng} / \mathrm{mL})$ and normal function of other pituitary axes.

Conclusion: To the best of our knowledge this is the first confirmed case of an isolated GH deficiency in a patient with ICA agenesis. The presence of an isolated pituitary deficit is unlike to be considered only as an effect of hemodynamic mechanism, suggesting a role for genetic factor(s) as a common cause of these two rare birth defects. Further studies could clarify this issue and the underlying mechanisms to better understand the etiopathogenetic characteristics of this disorder.
\end{abstract}

\section{Background}

Agenesis, aplasia and hypoplasia of the internal carotid artery (ICA) are rare congenital vascular malformations [1]. Of these, agenesis of the ICA is an extremely rare vascular anomaly occurring in less than $0.01 \%$ of the population [2]. A 3:1 left side predominance in the ICA agenesis has been reported [1].

Agenesis of the ICA is rarely associated with congenital hypopituitarism $(\mathrm{CH})$ [3]. $\mathrm{CH}$ is also a very rare congenital manifestation presenting either as an isolated hormone deficiency-the most common of which is isolated growth hormone deficiency (IGHD)—or multiple pituitary hormone involvement (combined pituitary hormone deficiencies (CPHD)) [4].

\footnotetext{
* Correspondence: stefano.stagi@yahoo.it

'Paediatric Endocrinology Unit, Health Sciences Department, University of Florence, Anna Meyer Children's University Hospital, Viale Pieraccini 24, 50139 Florence, Italy

Full list of author information is available at the end of the article
}

The etiology of this association is not clear: even if the blocking of a unilateral blood supply might cause the pituitary hypoplasia, a possible genetic cause, such as complex neural crest differentiation and/or migration disorders, cannot be excluded.

To the best of our knowledge, no more than 12 cases of CPHD associated with ICA have been reported [2, 5-14] (Table 1). However, a case of transient IGHD has been also described even though it may be caused by a reduced flow because of a focal stenosis in the right distal internal carotid artery and right middle cerebral artery due to a moyamoya [15]. Given the rarity of these two conditions, the association is unlikely to be causal, although this possibility cannot be excluded. In this report, we describe for the first time a 17-year-old boy with a confirmed diagnosis of IGHD and we review the literature and discuss the etiology of this association.

Ciomed Central

(c) 2015 Stagi et al. This is an Open Access article distributed under the terms of the Creative Commons Attribution License (http://creativecommons.org/licenses/by/4.0), which permits unrestricted use, distribution, and reproduction in any medium, provided the original work is properly credited. The Creative Commons Public Domain Dedication waiver (http:// creativecommons.org/publicdomain/zero/1.0/) applies to the data made available in this article, unless otherwise stated. 


\section{Case report}

The patient was a 17-year-old boy on rhGH therapy for 14 years because of a GH deficiency that was diagnosed at the age of 2 years and 3 months. Therapy was stopped 9 months before the beginning of symptoms-fatigue, decreased muscle strength and severe headache. However, the patient had not come for retesting one month after discontinuation of rhGH treatment.

The propositus was the first child of non-consanguineous Italian parents. The mother was in treatment for postpartum depression. The maternal grandfather was in treatment for autoimmune hyperthyroidism.

The mother's height was $152 \mathrm{~cm}$ and she had menarche at the age of 13; the father's height was $168 \mathrm{~cm}$ and he had a normal development. The target height was $166.0 \pm 6.0 \mathrm{~cm}(-1.70 \mathrm{SDS})$. All auxological data were normalized for chronological age by conversion to standard deviation scores (SDS) that were calculated according to the following formula: patient value - mean of age-related reference value/standard deviation of the age-related reference value [16].

The child was born at 40 weeks of gestation with an uncomplicated delivery. The birth weight was $2970 \mathrm{~g}$ $(-1.15 \mathrm{SDS})$, length at birth was $50 \mathrm{~cm}(-0.30 \mathrm{SDS})$, and his occipito-frontal head circumference (OFC) was $34 \mathrm{~cm}(-0.61$ SDS). He had neonatal jaundice requiring phototherapy. The child's neuromotor development was normal: he sat at 6 months, walked independently at 12 months, and began to use language at 14 months.

At 6 months, the patient exhibited very deficient growth (Fig. 1a and b). At 2 years and 3 months, he was admitted to our Paediatric Endocrine Unit for an endocrinological evaluation. His height, evaluated according the growth charts compiled by Cacciari et al. [17], was $78.6 \mathrm{~cm}(-2.79$ SDS $)$. His weight was $9.830 \mathrm{~kg}(-2.78$ SDS), and his BMI was 15.91 (-0.28 SDS) (Fig. 1a-d). Extensive biochemical, endocrinological and metabolic examinations did not reveal any abnormalities with the exception of plasma concentrations of IGF-I and IGFBP3 that were low for his age and sex: $27 \mathrm{ng} / \mathrm{mL}$ and $1.38 \mu \mathrm{g} / \mathrm{mL}$, respectively. Thus, GH stimulation tests were performed and showed a reduced response after the clonidine (GH peak of $5.2 \mathrm{ng} / \mathrm{mL}$ ) and insulin (glucose nadir $2.0 \mathrm{mmol} / \mathrm{L}$ at $30 \mathrm{~min}$; $\mathrm{GH}$ peak of $3.9 \mathrm{ng} /$ $\mathrm{mL}$ ) tests. This revealed a GH deficiency (GHD). Bone age was assessed according to the Greulich and Pyle method [18], and it was delayed (1 year and 2 months versus a chronological age of 2 years and 3 months). Brain MRI of the hypophyseal region showed the presence of a pituitary hypoplasia (height $1.8 \mathrm{~mm}$ and width $2.7 \mathrm{~mm})$. Consequently, hGH therapy $(0.22 \mathrm{mg} / \mathrm{kg} / \mathrm{wk})$ was started.

The child responded very well to rhGH treatment (Fig. 1c) and at 3 years and 4 months old, his height was
$94.5 \mathrm{~cm}(-1.14 \mathrm{SDS})$, weight $12.450 \mathrm{~kg}(-2.10 \mathrm{SDS})$, height velocity $15.06 \mathrm{~cm} / \mathrm{yr}$ (5.05 SDS), and BMI 13.94 $(-1.75$ SDS). At 4 years and 3 months old, his height was $101.9 \mathrm{~cm}$ (-0.82 SDS), his weight was $15.300 \mathrm{~kg}$ (-1.24 SDS), his height velocity was $8.05 \mathrm{~cm} / \mathrm{yr}(1.12$ SDS), and his BMI was 14.73 (-0.82 SDS).

The onset of puberty occurred at 12 years old with normal onset, timing, tempo, and magnitude of pubertal changes [19]. He stopped rhGH treatment at 16 years and 3 months old when he reached the definitive stature [16]: his height was $170.8 \mathrm{~cm}(-0.64$ SDS) and his weight was $51.800 \mathrm{~kg}(-1.56 \mathrm{SDS})$ with a BMI of $17.76(-1.63$ SDS) (Fig. 1c and d).

At 17 years old, his GH secretion was re-tested by the growth-hormone-releasing hormone $(\mathrm{GHRH})+$ arginine test, which is a reliable test of ITT in retesting patients who had undergone GH treatment in childhood [20]. The test confirmed a severe GH deficiency (basal GH value of $0.18 \mathrm{ng} / \mathrm{mL}$; GH peak of $2.42 \mathrm{ng} / \mathrm{mL}$ ).

MRI angiography was performed because of the severe growth hormone deficiency (GHD) and headache; it confirmed the presence of adenohypophyseal hypoplasia (height $2.5 \mathrm{~mm}$ and width $3.5 \mathrm{~mm}$ ) with a lack of posterior pituitary hyperintensity. The MRI angiography also showed the absence of a normal flow void in the left ICA (Fig. 2).

No abnormal findings were noted in the electrocardiogram. Chromosomal studies of the peripheral lymphocyte cultures revealed a 46,XY normal male karyotype. An array of CGH analyses on the patient's DNA was performed with an Agilent $60 \mathrm{~K}$ array platform with a resolution of approximately $100 \mathrm{~kb}$. No genomic imbalances were detected. A complete examination was performed with particular attention to neurology, metabolism, and endocrinology (Table 2). The only abnormal result was a very low IGF-I value $(31 \mathrm{ng} / \mathrm{mL})$. In light of these results, the patient restarted rhGH therapy, and his symptoms at the time of referral disappeared.

\section{Discussion}

ICA agenesis is a rare congenital abnormality that is very rarely associated with $\mathrm{CH}$. All reported cases refer to patients with CPHD and ICA agenesis although many of these reports did not describe-or only poorly described-the possible associated endocrinological abnormalities and treatments. This had led many to hypothesize a vascular cause of pituitary disorders. Two different theories involving the hemodynamic mechanisms or disorders of differentiation and/or migration of the neural crest have been reported [2].

The ICA originates from the third aortic arch during embryogenesis. However, it is controversial whether the common and external carotids really originate from the same third aortic arch or from the aortic sac [21]. In 
Table 1 Review of endocrinological and anatomical characteristics of patients with congenital hypopituitarism and internal carotid malformations

\begin{tabular}{|c|c|c|c|c|c|c|c|}
\hline & Sex & Age & Pituitary MRI & Internal carotid RMI & Other characteristics & $\begin{array}{l}\text { Molecular } \\
\text { studies }\end{array}$ & References \\
\hline 1 & $\mathrm{~N}$ & $\mathrm{~N}$ & $\begin{array}{l}\text { Not specified (except } \\
\text { for normal posterior pituitary). }\end{array}$ & $\begin{array}{l}\text { Absence of ICA and carotid } \\
\text { canal. }\end{array}$ & Not specified. & NP & {$[14]$} \\
\hline 2 & M & $18 \mathrm{~m}$ & Pituitary hypoplasia. & Anomaly of right ICA. & $\begin{array}{l}\text { TSH, GH, ACTH deficiency. Central } \\
\text { diabetes insipidus. Possible } \\
\text { hypogonadism. }\end{array}$ & NP & [13] \\
\hline 3 & $\mathrm{~F}$ & $5 \mathrm{~m}$ & $\begin{array}{l}\text { Absence of anterior pituitary } \\
\text { and ectopic pituitary } \\
\text { posterior lobe. }\end{array}$ & $\begin{array}{l}\text { Absence of right common carotid } \\
\text { artery, right ICA, right anterior } \\
\text { cerebral artery. }\end{array}$ & $\begin{array}{l}\text { TSH, ACTH and GH deficiency. No } \\
\text { evidence of diabetes insipidus. Genitalia } \\
\text { were normal. Single central maxillary } \\
\text { incisor. }\end{array}$ & NP & [7] \\
\hline 4 & M & 23 year & $\begin{array}{l}\text { Absence of anterior pituitary } \\
\text { and ectopic pituitary } \\
\text { posterior lobe. }\end{array}$ & $\begin{array}{l}\text { Absence of right ICA and carotid } \\
\text { canal and } A 1 \text { segment of the right } \\
\text { anterior cerebral artery. }\end{array}$ & $\begin{array}{l}\text { Congenital microphthalmia with } \\
\text { cataract and coloboma of the right eye, } \\
\text { encephalocele. Hormonal substitution } \\
\text { treatments not specified. }\end{array}$ & NP & {$[5]$} \\
\hline 5 & M & 37 year & Absence of anterior pituitary. & $\begin{array}{l}\text { Hypoplasia of right ICA and } \\
\text { carotid canal. }\end{array}$ & $\begin{array}{l}\text { Amblyopia of the left eye caused by an } \\
\text { optic nerve coloboma, encephalocele. } \\
\text { Hormonal substitution treatments not } \\
\text { specified. }\end{array}$ & NP & {$[5]$} \\
\hline 6 & $\mathrm{~F}$ & 29 year & $\begin{array}{l}\text { Pituitary hypoplasia and } \\
\text { ectopic pituitary posterior } \\
\text { lobe. }\end{array}$ & $\begin{array}{l}\text { Absence of right ICA, carotid canal, } \\
\text { and } A 1 \text { segment of the right } \\
\text { anterior cerebral artery. }\end{array}$ & $\begin{array}{l}\text { TSH, ACTH, and GH deficiency. No } \\
\text { evidence of diabetes insipidus. } \\
\text { Hypogonadism. Chiari I malformation } \\
\text { with syringomyelia. }\end{array}$ & NP & [9] \\
\hline 7 & M & 5 year & $\begin{array}{l}\text { Absence of anterior pituitary } \\
\text { and ectopic pituitary } \\
\text { posterior lobe. }\end{array}$ & $\begin{array}{l}\text { Absence of left ICA and carotid } \\
\text { canal, A1 segment of the left } \\
\text { anterior cerebral artery and the } \\
\text { anterior communicating artery. }\end{array}$ & $\begin{array}{l}\text { Retrognathia, microphallus, and } \\
\text { cryptorchidism. TSH, ACTH, GH } \\
\text { deficiency, but no evidence of diabetes } \\
\text { insipidus. Possibile hypogonadism. }\end{array}$ & NP & {$[10]$} \\
\hline 8 & M & 11 year & Pituitary hypoplasia & $\begin{array}{l}\text { Absence of left ICA and carotid } \\
\text { canal; hypoplasia of A1 segment of } \\
\text { left anterior cerebral artery }\end{array}$ & $\begin{array}{l}\text { TSH, ACTH, GH deficiency. Central } \\
\text { diabetes insipidus. Microphallus with } \\
\text { possible hypogonadism. }\end{array}$ & NP & {$[6]$} \\
\hline 9 & $\mathrm{~F}$ & 10 year & $\begin{array}{l}\text { Hypoplastic anterior pituitary, } \\
\text { flat sella turcica, absent } \\
\text { pituitary stalk }\end{array}$ & $\begin{array}{l}\text { Agenesis of the left ICA and the } \\
\text { left carotid canal }\end{array}$ & $\begin{array}{l}\text { GH, TSH, gonadotropin deficiency. No } \\
\text { evidence of diabetes insipidus. Born out } \\
\text { of a consanguineous marriage. }\end{array}$ & $\begin{array}{l}\text { No } \\
\text { HESX1, } \\
\text { LHX4, } \\
\text { OTX2 } \\
\text { mutations }\end{array}$ & {$[8]$} \\
\hline 10 & $\mathrm{~F}$ & $\begin{array}{l}7 \\
\text { month }\end{array}$ & $\begin{array}{l}\text { Adenohypophyseal } \\
\text { hypoplasia with a lack of } \\
\text { posterior pituitary } \\
\text { hyperintensity }\end{array}$ & Absence of the left ICA & $\begin{array}{l}\text { Desaturation episodes, recurrent } \\
\text { respiratory infections. Short hands and } \\
\text { feet. GH, ACTH and TSH deficiency. }\end{array}$ & $\begin{array}{l}17 q 24.2 \\
\text { deletion }\end{array}$ & [3] \\
\hline 11 & $\mathrm{~F}$ & 2 year & $\begin{array}{l}\text { Adenohypophyseal } \\
\text { hypoplasia with a lack of } \\
\text { posterior pituitary } \\
\text { hyperintensity }\end{array}$ & Absence of the right ICA & $\begin{array}{l}\text { GH, TSH, and gonadotropin deficiency. } \\
\text { No clinical evidence of diabetes } \\
\text { insipidus. }\end{array}$ & NP & [11] \\
\hline 12 & M & 3 week & $\begin{array}{l}\text { Absence of anterior pituitary } \\
\text { with ectopic posterior } \\
\text { pituitary }\end{array}$ & $\begin{array}{l}\text { Absence of the left ICA and } \\
\text { carotid canal }\end{array}$ & $\begin{array}{l}\text { GH, TSH, ACTH and gonadotropin } \\
\text { deficiency. Microphallus. }\end{array}$ & NP & {$[12]$} \\
\hline 13 & M & 17 year & $\begin{array}{l}\text { Adenohypophyseal } \\
\text { hypoplasia with a lack of } \\
\text { posterior pituitary } \\
\text { hyperintensity }\end{array}$ & Agenesis of the left ICA & $\begin{array}{l}\text { GH deficiency. No other pituitary } \\
\text { deficiencies. No clinical evidence of } \\
\text { diabetes insipidus. }\end{array}$ & $\begin{array}{l}\text { Normal } \\
\text { array-CGH }\end{array}$ & Our case \\
\hline
\end{tabular}

patients presenting a vascular anomaly of the ICA, the blood supply of the affected side is partially or completely compensated by the vertebrobasilar or contralateral ICA system. This is characterized by the enlargement of a normally existing segment or presence of abnormal or persisting fetal arteries [22]. In most patients, this vascular anomaly is asymptomatic [23], and the rarity of a pediatric
ICA agenesis diagnosis suggests that the arterial collateral pathways are initially sufficient to support cerebral perfusion [24]. However, some patients may experience recurrent headaches, blurred vision, hemiparesis, and hypopituitarism $[25,26]$ likely due to cerebrovascular insufficiency, compression by collateral vessels, or associated cerebral aneurysms [21]. Moreover, the symptoms 

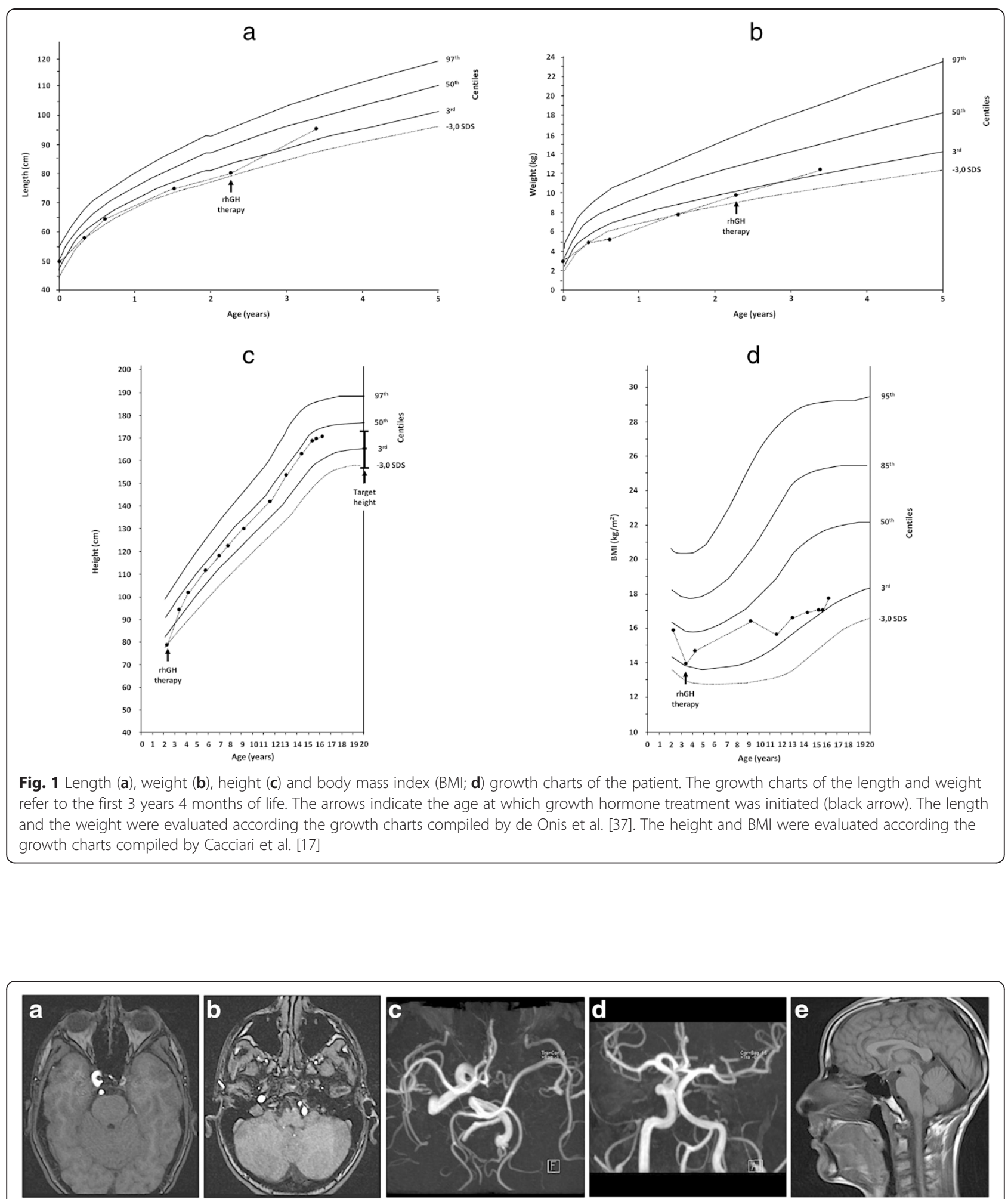

Fig. 2 A MRI angiography time-of-flight (TOF) three-dimensional (3D) technique through the circle of Willis revealed agenesis of the intracranial portion of the left internal carotid artery (ICA). a. 3D TOF in the axial plane at the carotid siphon level shows agenesis of the left ICA. b. 3D TOF in the axial plane for the vertebrobasilar system shows the left vertebral artery and the compensatory hypertrophy. $\mathbf{c}$. MRI angiography maximum intensity projection (MIP) reconstruction in the axial plane reveals agenesis of the intracranial portion of the left ICA. $\mathbf{d}$. MRI angiography MIP reconstruction in the coronal plane highlights hypertrophy in the left vertebral collateral blood flow. e. Sagittal TIW TSE sequence shows adenohypophyseal hypoplasia (height $2.5 \mathrm{~mm}$ and width $3.5 \mathrm{~mm}$ ) with a lack of posterior pituitary hyperintensity 
Table 2 Laboratory results at left ICA agenesis diagnosis

\begin{tabular}{|c|c|c|c|c|c|}
\hline & Value & Reference values & & Value & Reference values \\
\hline FreeT4, pmol/L & 12.4 & $10.3-19.4$ & $\mathrm{HbA1c}, \%$ & 4.4 & $<5.5$ \\
\hline $\mathrm{TSH}, \mathrm{mIU} / \mathrm{L}$ & 1.20 & $0.40-4.0$ & $\mathrm{Na}^{+}, \mathrm{mEq} / \mathrm{L}$ & 138 & $135-145$ \\
\hline Cortisol, $\mu \mathrm{g} / \mathrm{dL}$ & 16.8 & $5.0-19.0$ & $\mathrm{~K}^{+}, \mathrm{mEq} / \mathrm{L}$ & 4.2 & $3.5-5.0$ \\
\hline $\mathrm{ACTH}, \mathrm{ng} / \mathrm{L}$ & 25.7 & $9.0-52.0$ & $\mathrm{Cl}^{-}, \mathrm{mEq} / \mathrm{L}$ & 101 & $95-105$ \\
\hline Prolactin, mIU/L & 271 & $87.0-392.0$ & Plasma osmolality, mOsm/kg & 295 & $280-300$ \\
\hline Total testosterone, ng/mL & 378 & $270.0-1070.0$ & Urine Osmolality, mOsm/kg & 1037 & $400-1100$ \\
\hline
\end{tabular}

TSH thyroid-stimulating hormone, ACTH adrenocorticotrophic hormone

reported by our patient were probably the result of both GHD (fatigue, decreased muscle strength, etc.) and ICA agenesis (headache).

Only one of the 13 patients previously described in the literature had MRI evidence of associated vascular defects. This patient had transient GH deficiency and was described by Quah et al. [15]. This patient's pituitary defects and neurological symptoms may have been caused by reduced flow due to a focal stenosis of the other distal internal carotid artery and right middle cerebral artery due to a moyamoya [15]. However, the presence of a defect in the vascular perfusion is difficult to reconcile with the pituitary anatomical abnormalities and with the variability of the endocrinological defects reported including isolated GH deficiency or central diabetes insipidus (described only rarely) $[6,15]$.

The ICA is formed in embryos during the fourth week from the third aortic arch arteries and during the fifth and sixth weeks from the terminal segments of the dorsal aorta [27]. Conversely, the pituitary gland fully develops due to merging of the Rathke pouch and the infundibulum by the eighth week of gestation. The blood supply of the anterior and posterior pituitary gland comes from the bilateral superior and inferior hypophyseal arteries arising from the ICA [28]. It is not clear why pituitary hypoplasia would result from blocking of a unilateral blood supply and from abnormalities of the hypophyseal anatomy such as adenohypophysis hypoplasia and aplasia. However, the presence of ectopic neurophypophysis, which has been described in some patients, or other hypophyseal abnormalities, may also suggest a genetic etiology.

Pituitary gland development and function depend on the sequential temporal and spatial expression of multiple transcription factor genes such as POU1F1 (POU class 1 homeobox 1; OMIM 173110), PROP1 (prophet of PIT1; OMIM 601538), HESX1 (homeobox gene expressed in ES cells; OMIM 601802), LHX3 (LIM homeobox gene 3; OMIM 600577), LHX4 (LIM homeobox gene 4; OMIM 602146), SOX3 (SRY-related HMG-box gene 3; OMIM 313430), and OTX2 (orthodenticle homolog 2; OMIM 600037) [4]. However, these defects may cause a deficiency in one or more pituitary hormones. Its clinical features vary in both severity and time of presentation, and onset may occur in the neonatal period or develop later in life [29-31]. In some patients, the hormonal deficiencies may present as a part of a syndrome with patients manifesting abnormalities in structures that share a common embryological origin with the pituitary gland [29-31].

In our review 6 patients, in addition to our, had a pituitary hypoplasia $[3,6,8,9,11,13]$. This abnormality was isolated in two cases $[6,13]$, associated with ectopic neurohypophysis [9], absent pituitary stalk [8], or associated with a lack of posterior pituitary hyperintensity $[3,11]$. However 5 patients had an absent adenohypophysis $[5,7,10,12]$ and 4 associated of these showed an ectopic neurohypophysis $[5,7,10,12]$.

Moreover, ectopic neurohypophysis may be accompanied by midline brain defects [32] supporting an embryological defect due to genetic factors [32, 33]. This has been reported in idiopathic GH deficiency or in subjects with HESX1, LHX4, and SOX3 gene mutations [34]. For example, both the SOX3 under- and over-expression may result in CPHD or IGHD in males, associated with infundibular hypoplasia, ectopic/undescended posterior pituitary, and abnormalities of the corpus callosum [35]. In these patients, congenital abnormalities of the ICA or other vessels have not been reported [35]. However, the associated midline anomalies (coloboma, single central maxillary tooth, transsphenoidal encephalocele, and Chiari I malformation) reported in some cases $[5,7,9,15]$ may support this hypothesis.

Of the patients in our review, one case had unilateral agenesis of the internal carotid artery associated with CPHD without HESX1, LHX4, or OTX2 mutations [8]. Moreover, Savasta et al. [3] recently reported a CNV (copy number variant) i.e. a paternally inherited 200-kb deletion in 17q24.2. Thus, we performed array-CGH in our patient, but discovered no genomic imbalances. However, we indicate the need for further molecular analysis by NGS techniques to discover possible molecular abnormalities associated with this syndrome.

Given the rarity of the two conditions, the association is unlikely to be causal, although this cannot be excluded [36]. So, we hypothesize that an unknown gene mutation 
is the most likely explanation for the anatomical defects seen in these patients, suggesting a role for genetic factor(s) as a common cause of these two birth defects.

\section{Conclusions}

Here were report the first case of a confirmed isolated GH deficiency in a patient with ICA agenesis. Our experience suggests the opportunity to carefully evaluate possible vascular abnormalities in case of IGHD or CPHD. The presence of an isolated pituitary deficit, and the rare association between the two conditions, suggest a genetic rather than a hemodynamic mechanism. Further studies, especially with NGS-based molecular analysis, could clarify this issue and the underlying mechanisms to better understand the etiopathogenetic characteristics of this disorder.

\section{Consent}

Parents of the patient provided written informed consent for publication of this Case Report and any accompanying images. A copy of the written consent is available for review by the Editor of this Journal.

\section{Additional file}

Additional file 1: CARE guidelines checklist of our Case Report.

(DOCX $14 \mathrm{~kb}$ )

\begin{abstract}
Abbreviations
ACTH: Adrenocorticotrophic hormone; $\mathrm{CH}$ : Congenital hypopituitarism; CPHD: Combined pituitary hormone deficiencies; GH: Growth hormone; GHD: Growth hormone deficiency; GHRH: Growth-hormone-releasing hormone; ICA: Internal carotid artery; IGHD: Isolated growth hormone deficiency; MRI: Magnetic resonance image; TSH: Thyroid-stimulating hormone.
\end{abstract}

\section{Competing interests}

Stefano Stagi (SStagi), Giovanna Traficante (GT), Elisabetta Lapi (EL), Marilena Pantaleo (MP), Sabrina Becciani (SB), Marzia Mortilla (MM), Salvatore Seminara (SSeminara) and Maurizio de Martino (MdM) have no financial interests to disclose and no conflict of interest to declare.

\begin{abstract}
Authors' contributions
SStagi carried out the endocrinological evaluation, conceived of the study, and participated in its design. GT performed the clinical genetic evaluation, conceived of the study, and participated in its design. EL performed the clinical genetic evaluation, and revised critically the manuscript. MP performed the molecular genetic studies, participated in the acquisition of data, and was involved in drafting the manuscript. SB performed the endocrinological evaluation, participated in the acquisition of data, and was involved in drafting the manuscript. MM performed the neuroradiological evaluation, was involved in drafting, and revised critically the manuscript. SSeminara performed the endocrinological evaluation and revised critically the manuscript. MdM participated in the endocrinological evaluation and participated in its coordination. All authors read and approved the final manuscript.
\end{abstract}

\section{Acknowledgements}

The authors would like to thank the patient's family.

\section{Author details}

${ }^{1}$ Paediatric Endocrinology Unit, Health Sciences Department, University of Florence, Anna Meyer Children's University Hospital, Viale Pieraccini 24, 50139 Florence, Italy. ${ }^{2}$ Genetics and Molecular Medicine Unit, Anna Meyer Children's University Hospital, Florence, Italy. ${ }^{3}$ Radiology Unit, Anna Meyer Children's University Hospital, Florence, Italy.

Received: 25 February 2015 Accepted: 24 July 2015

Published online: 19 October 2015

\section{References}

1. Clarós P, Bandos R, Gilea I, Clarós Jr A, Capdevila A, García Rodríguez J, et al. Major congenital anomalies of the internal carotid artery: agenesis, aplasia and hypoplasia. Int J Pediatr Otorhinolaryngol. 1999;49:69-76.

2. Lee $\mathrm{JH}, \mathrm{Oh} \mathrm{CW}$, Lee $\mathrm{SH}, \mathrm{Han} \mathrm{DH}$. Aplasia of the internal carotid artery. Acta Neurochir (Wien). 2003;145:117-25.

3. Savasta S, Merli P, Introzzi F, Strocchio L, Lanati G, Incorpora G, et al. Agenesis of internal carotid artery and hypopituitarism: case report and review of literature. J Clin Endocrinol Metab. 2012;97:3414-20.

4. Kelberman D, Rizzoti K, Lovell-Badge R, Robinson IC, Dattani MT. Genetic regulation of pituitary gland development in human and mouse. Endocr Rev. 2009:30:790-829.

5. Blustajn J, Netchine I, Frédy D, Bakouche P, Piekarski JD, Meder JF. Dysgenesis of the internal carotid artery associated with transsphenoidal encephalocele: a neural crest syndrome? AJNR Am J Neuroradiol. 1999:20:1154-7.

6. Inamo Y, Harada K. Agenesis of the internal carotid artery and congenital pituitary hypoplasia: proposal of a cause of congenital hypopituitarism. Eur J Pediatr. 2003;162:610-2.

7. Kjellin IB, Kaiserman KB, Curran JG, Geffner ME. Aplasia of right internal carotid artery and hypopituitarism. Pediatr Radiol. 1999;29:586-8.

8. Lamine F, Kanoun F, Chihaoui M, Saveanu A, Menif E, Barlier A, et al. Unilateral agenesis of internal carotid artery associated with congenital combined pituitary hormone deficiency and pituitary stalk interruption without HESX1, LHX4 or OTX2 mutation: a case report. Pituitary. 2012;15 Suppl 1:S81-6.

9. Mellado JM, Merino X, Ramos A, Salvadó E, Saurí A. Agenesis of the internal carotid artery with a trans-sellar anastomosis: CT and MRI findings in late-onset congenital hypopituitarism. Neuroradiology. 2001:43:237-41.

10. Moon WJ, Porto L, Lanfermann H, Weis R, Zanella FE. Agenesis of internal carotid artery associated with congenital anterior hypopituitarism. Neuroradiology. 2002;44:138-42.

11. Seixas D, Ayres-Basto M, Fontoura M, Silva ML, Fonseca J. Agenesis of the internal carotid artery and hypogenesis of the pituitary gland: cause, consequence or coincidence? Neuroradiol J. 2006;19:629-32.

12. Shulman DI, Martinez CR. Association of ectopic posterior pituitary and anterior pituitary hypoplasia with absence of the left internal carotid. J Pediatr Endocrinol Metab. 1996;9:539-42.

13. Tanaka R, Tokuda M, Shinakawa S, Okasora K, Suzuki S, Konishi K. A multiple pituitary hormone deficiency patient with anomaly of internal carotid artery, Proc 21 st International Symposium on Growth Hormone and Growth Factors in Endocrinology and Metabolism, Venice. 1996.

14. Triulzi F, Scotti G, di Natale B, Pellini C, Lukezic M, Scognamiglio M, et al. Evidence of a congenital midline brain anomaly in pituitary dwarfs: a magnetic resonance imaging study in 101 patients. Pediatrics. 1994;93:409-16.

15. Quah BL, Hamilton J, Blaser S, Héon E, Tehrani NN. Morning glory disc anomaly, midline cranial defects and abnormal carotid circulation: an association worth looking for. Pediatr Radiol. 2005;35:525-8.

16. Stagi S, Galli L, Cecchi C, Chiappini E, Losi S, Gattinara CG, et al. Final height in patients perinatally infected with the human immunodeficiency virus. Horm Res Paediatr. 2010;74:165-71.

17. Cacciari E, Milani S, Balsamo A, Spada E, Bona G, Cavallo L, et al. Italian cross-sectional growth charts for height, weight and BMI (2 to 20 year). J Endocrinol Invest. 2006:29:581-93.

18. Greulich WW, Pyle SI. Radiographic Atlas of Skeletal Development of the Hand and Wrist. Stanford, CA: Stanford University Press; 1959.

19. Tanner JM, Whitehouse RH. Clinical longitudinal standards for height, weight, height velocity, weight velocity, and stages of puberty. Arch Dis Child. 1976;51:170-9.

20. Aimaretti G, Baffoni C, Bellone S, Di Vito L, Corneli G, Arvat E, et al. Retesting young adults with childhood-onset growth hormone $(\mathrm{GH})$ deficiency with GH-releasing-hormone-plus-arginine test. J Clin Endocrinol Metab. 2000;85:3693-9. 
21. Quint DJ, Boulos RS, Spera TD. Congenital absence of the cervical and petrous internal carotid artery with intercavernous anastomosis. AJNR Am J Neuroradiol. 1989;10:435-9.

22. Midkiff RB, Boykin MW, McFarland DR, Bauman JA. Agenesis of the internal carotid artery with intercavernous anastomosis. AJNR Am J Neuroradiol. 1995;16:1356-9.

23. Elazab NE, Riel-Romero RM, Gonzalez-Toledo E. Internal carotid artery agenesis and basilar artery aneurysm with third nerve palsy. Pediatr Neurol. 2010;42:451-4.

24. Mayer PL, Leon Kier E. The ontogenetic and phylogenetic basis of cerebrovascular anomalies and variants. In: Apuzzo MLJ, editor. Brain Surgery: Complications, avoidance and management. 1st ed. New York: Churchill and Livingstone; 1993. p. 741-7.

25. Florio F, Balzano S, Nardella M, Strizzi V, Cammisa M, Bozzini V, et al. Congenital absence of the internal carotid artery. Cardiovasc Intervent Radiol. 1999;22:74-8.

26. Harps $E_{1}$ Helmke K. Diagnosis of congenital absence of internal carotid artery by power angio sonography. Eur Radiol. 1998:8:1245-7.

27. Padget $\mathrm{DH}$. The development of the cranial arteries in the human embryo. Contrib Embryol Carnegie Inst. 1948;32:205-61.

28. Lasjaunias P, Santoyo-Vazquez A. Segmental agenesis of the internal carotid artery: angiographic aspects with embryological discussion. Anat Clin. 1984;6:133-41.

29. Kelberman D, Dattani MT. Hypopituitarism oddities: congenital causes. Horm Res. 2007;68 Suppl 5:138-44.

30. Alatzoglou KS, Dattani MT. Genetic forms of hypopituitarism and their manifestation in the neonatal period. Early Hum Dev. 2009;85:705-12.

31. Romero CJ, Pine-Twaddell E, Radovick S. Novel mutations associated with combined pituitary hormone deficiency. J Mol Endocrinol. 2011;46:R93-R102.

32. Ultmann MC, Siegel SF, Hirsch WL, Finegold DN, Foley Jr TP. Pituitary stalk and ectopic hyperintense T1 signal on magnetic resonance imaging. Implications for anterior pituitary dysfunction. Am J Dis Child. 1993;147:647-52.

33. Chen S, Léger J, Garel C, Hassan M, Czernichow P. Growth hormone deficiency with ectopic neurohypophysis: anatomical variations and relationship between the visibility of the pituitary stalk asserted by magnetic resonance imaging and anterior pituitary function. J Clin Endocrinol Metab. 1999:84:2408-13.

34. di lorgi N, Secco A, Napoli F, Calandra E, Rossi A, Maghnie M. Developmental abnormalities of the posterior pituitary gland. Endocr Dev. 2009;14:83-94

35. Stagi S, Lapi E, Pantaleo M, Traficante G, Giglio S, Seminara S, et al. A SOX3 (Xq26.3-27.3) duplication in a boy with growth hormone deficiency, ocular dyspraxia, and intellectual disability: a long-term follow-up and literature review. Hormones (Athens). 2014;13:552-60.

36. Thomas M, Massa G, Craen M, de Zegher F, Bourguignon JP, Heinrichs C, et al. Prevalence and demographic features of childhood growth hormone deficiency in Belgium during the period 1986-2001. Eur J Endocrinol. 2004;151:67-72.

37. de Onis M, Onyango AW, Borghi E, Garza C, Yang H, WHO Multicentre Growth Reference Study Group. Comparison of the World Health Organization (WHO) Child Growth Standards and the National Center for Health Statistics $\mathrm{WHO}$ international growth reference: implications for child health programmes. Public Health Nutr. 2006;9:942-7.

\section{Submit your next manuscript to BioMed Central and take full advantage of:}

- Convenient online submission

- Thorough peer review

- No space constraints or color figure charges

- Immediate publication on acceptance

- Inclusion in PubMed, CAS, Scopus and Google Scholar

- Research which is freely available for redistribution 